\title{
Evaluation of diverse range microbes for their plant growth promoting abilities and their pesticide compatibility
}

Sanam Tulja 四

Department of Agricultural Microbiology and Bioenergy, Professor Jayashankar Telangana State Agriculture University, Hyderabad, India S. Triveni

Department of Agricultural Microbiology and Bioenergy, Professor Jayashankar Telangana State Agriculture University, Hyderabad, India

J. Satyanaryana

Department of Entomology, Professor Jayashankar Telangana State Agriculture University, Hyderabad, India

Sridhar Goud Nerella

Department of Medicinal chemistry, National Institute of Pharmaceutical Education and Research (NIPER), Hyderabad, India

K. Damodara Chari

Assistant Scientific Officer for Microbiology, National Institute of Plant Health Management, Hyderabad, India

Suseelendra Desai

Indian Council of Agricultural Research (ICAR)-Central Research Institute for Dryland Agriculture (CRIDA), Hyderabad, India

\begin{tabular}{|c|c|}
\hline ARTICLE INFO & ABSTRACT \\
\hline $\begin{array}{l}\text { Received : } 25 \text { May } 2021 \\
\text { Revised : } 27 \text { June } 2021 \\
\text { Accepted : } 10 \text { July } 2021 \\
\text { Available online: } 19 \text { November } 2021 \\
\text { Key Words: } \\
\text { Atomic absorption spectrophotometry } \\
\text { Flame photometer } \\
\text { Pesticides } \\
\text { Rhizobacteria } \\
\text { Phytohormones }\end{array}$ & $\begin{array}{l}\text { Plant growth-promoting rhizobacteria (PGPR) contribute to an increase in crop } \\
\text { yield through an environmentally friendly method, therefore eight rhizospheric } \\
\text { bacteria, two of each genera Bacillus, Pseudomonas, Azotobacter and } \\
\text { Azospirillum were examined for their efficacy to solubilize mineral nutrients } \\
\text { using atomic absorption spectrophotometry and a flame photometer. Their } \\
\text { potency to produce phytohormones, synthesis biocontrol components and their } \\
\text { compatibility with pesticides using in vitro assays was studied. All of the chosen } \\
\text { bacterial isolates proved positive for the above-mentioned Plant Growth } \\
\text { Promoting traits. Among the eight bacterial isolates Pseudomonas isolate P69 } \\
\text { showed the highest phosphorous solubilization efficiency of } 190.91 \text { \% and } \\
\text { another isolate P48 produced a maximum of } 27.63 \mu \mathrm{mL} \text { of gibberellic acid, } \\
\text { Bacillus isolate B120 could solubilize maximum amount of ZnO and } \mathrm{ZnCO} \\
\text { accounting for } 21.3 \mathrm{ppm} \text { and } 25.9 \mathrm{ppm} \text {, respectively, not merely in terms of } \\
\text { solubilization when compared to the other isolates, B120 produced the highest } \\
\text { levels of HCN (77.33 ppm TCC) and siderophores (48.87psu). On day } 9 \text { after } \\
\text { inoculation, Azotobacter isolate AZB17 performed effectively in potassium } \\
\text { solubilization of } 6.25 \mathrm{~m} \mathrm{~L}^{-1} \text { with a pH drop to } 3.83 \text {. The Azospirillum isolate } \\
\text { ASP25 outperformed all other isolates in terms of IAA production (22.64g } \mathrm{mL}^{-1} \text { ) } \\
\text { and Bacillus isolate B365 was found to be more compatible with eight different } \\
\text { pesticides used in the field at varying concentrations. All of these factors point } \\
\text { to the possibility of using these bacterial isolates B120, P48, P69, AZB17, and } \\
\text { ASP25 as biofertilizers in sustainable agriculture. }\end{array}$ \\
\hline
\end{tabular}

\section{Introduction}

With the growing global population, food being exploited to produce sustainable crop consumption is expected to rise annually and production systems around the world given by proportionately, resulting in the intensification of Bhattacharyya and Jha (2012), and one of the most agriculture for food security through the continued investigated areas is the exploitation of these use of synthetic fertilisers and pesticides to associations to produce sustainable crop production maximise yields (Nirmal et al., 2010). Plant- systems (Naqqash et al., 2016). In plant microbe associations inside the plant root zone are rhizospheres, there is a complicated interaction

Corresponding author E-mail: tuljasanam@gmail.com

Doi: https://doi.org/10.36953/ECJ.2021.22306

This work is licensed under Attribution-Non Commercial 4.0 International (CC BY-NC 4.0)

(C) ASEA 
between plant-root-soil bacteria. These complex interactions are thought to occur as a result of root exudations, which serve to attract beneficial soil microorganisms to the plant roots (Zhang et al., 2017; Mhlongo et al., 2018 ) As a result, plant rhizospheres sustain a large number of bacteria that are thought to promote plant growth rhizobacteria (PGPR) (Bhattacharyya and Jha, 2012). Rapid root colonisation is recognised as a necessity for PGP activities (Kamilova et al., 2015) and is hence one of the most important elements to consider when selecting rhizobacteria for business formation (Shafi et al., 2017). This PGPR are capable of increasing plant growth in a variety of ways, including nitrogen $\left(\mathrm{N}_{2}\right)$ fixation, nutrient solubilization and biogenesis of phytohormones (Somers et al., 2004), antibiotics, hydrolytic enzymes, siderophores (Beneduzi et al., 2012), and induced systematic resistance (ISR) in plants to their pathogens (Beneduzi et al., 2012), and are therefore terribly important in redressing soil fertility. For sustainable agricultural production, rhizobacterial-based solutions have been researched as alternatives to synthetic fertilisers. Pseudomonas, Azospirillum, Azotobacter, Enterobacter, Arthrobacter, Alcaligenes, Bacillus, and Acinetobacter are some of the most commonly investigated rhizobacteria. Wheat (Govindasamy et al., 2015), beans (Stefan et al., 2013), cucumber (Islam et al., 2016), and a variety of other crops have all demonstrated their promise (Hayat et al., 2010). It is obvious from this that members of the soil microbiome have a lot of potential in terms of encouraging sustainable crop management methods.

As the Plant Growth Promoting Microbes (PGPMs) are shown to benefit plants in many modes, the event of any PGP-based technology can facilitate in reducing the issues arising due to irrational use of inorganic fertilizers or artificial pesticides. However, it is evident that we tend to understand solely a small amount of microbe potential and an awfully flock remains to be done. In this backdrop, for sustainable and eco-friendly agriculture, a study was undertaken to screen the isolates of genus Bacillus sp., Pseudomonas sp., Azotobacter sp. and Azospirillum sp. for their PGP activity at the side of their compatibility with pesticides to use in the future as microbial inoculants that successively correlates to a reduction in environmental pollution due to the use of harmful fertilizers and pesticides thus ultimately leading to eco-friendly approach for crop yield attributes.

\section{Material and Methods}

In all, 31 strains of Azotobacter spp. (Az), 38 strains of Azospirillum spp. (As) spp., 82 fluorescent Pseudomonas spp. and 19 Bacillus spp. were isolated from rhizosphere soils of different cropping systems across 31 different agroclimatic regions from 13 states of India (Figure 1). As shown in Figure 1, it is evident that the collection of strains was done encompassing many states to cover diverse regions spread over different agroclimatic regions. By serial dilution of soil samples and plating on Jensen's agar (Jensen, 1940), N-free bromothymol blue media (Dobereiner et al., 1976), nutrient agar, and King's B (King et al., 1954) media Azotobacter, Azospirillum, Bacillus and Pseudomonas cultures were isolated, respectively. Standard biochemical conventional method tests were used to identify all of the bacterial strains to the genus level (Desai, 2012). Among them, eight bacterial isolates, two from each genus of Azotobacter (AZB17, AZB31), Azospirillum (ASP25, ASP34), Bacillus (B120, B365) and Pseudomonas (P48, P69) were randomly procured from ICAR-CRIDA culture bank. The cultures obtained were tested for their purity by plating on their specific media and were screened further for their PGP ability and their pesticide compatibility in vitro.

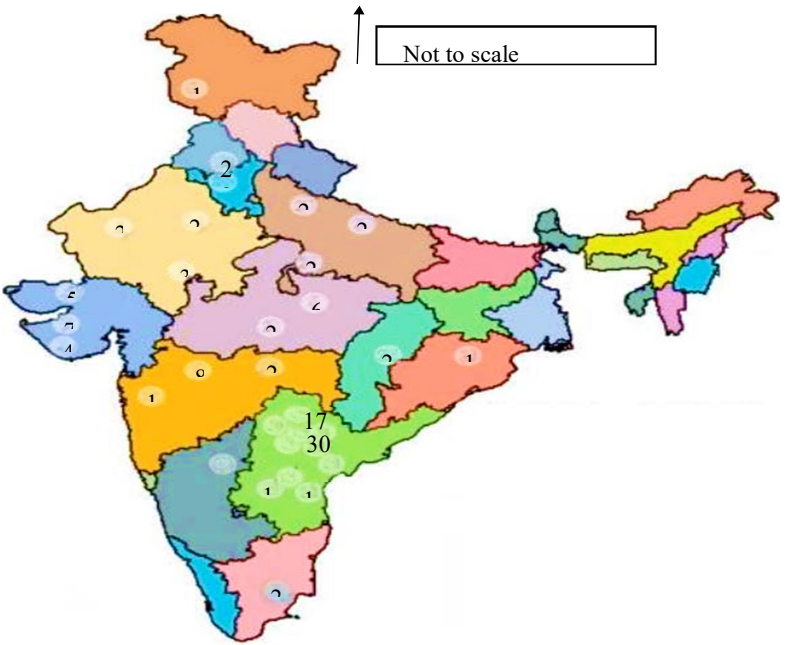

Figure 1: Map showing soils samples from different agro-ecosystems. Figures in parentheses in legends represent number of samples collected. 
Qualitative assay for Zinc (Zn), Potassium (K) and Phosphorus (P) solubilization

Two $\mu \mathrm{L}$ bacterial cultures were spot inoculated onto mineral salts agar medium amended with $0.1 \%$ of insoluble zinc oxide $(\mathrm{ZnO})$ and zinc carbonate $\left(\mathrm{ZnCO}_{3}\right)$. Aleksandrow's medium containing $0.5 \%$ potassium aluminium silicate (usually mica) as a source of an insoluble form of potassium and to assess phosphorous solubilization, Pikovskaya's medium amended with tricalcium phosphate (TCP) was used. All the inoculated plates were incubated at $28 \pm 2^{\circ} \mathrm{C}$ and solubilization zone (in $\mathrm{mm}$ ) was measured 15, 3 and 14 days after inoculation, respectively.

Solubilization Efficiency $(\mathrm{SE})=\frac{Z}{C} \times 100$; Solubilizing index $(\mathrm{SI})=C+\frac{Z}{C}$

Where, $\mathrm{Z}$ and $\mathrm{C}$ stand for clearance zone including bacterial growth and colony diameter, respectively.

Quantitative assay for zinc and potassium solubilization

All strains were tested quantitatively for $\mathrm{Zn}$ solubilization in mineral salts broth $(100 \mathrm{~mL})$ amended with 0.1 percent insoluble zinc salts $(\mathrm{ZnO}$ or $\mathrm{ZnCO}_{3}$ ) inoculated with $100 \mu \mathrm{L}$ of 24 hour old actively developed test bacterial cultures and cultured at $28^{\circ} \mathrm{C}$ for 10 days with shaking at 140 $\mathrm{rpm}$. On the $3^{\text {rd }}, 6^{\text {th }}$, and $9^{\text {th }}$ days of inoculation, samples were taken and centrifuged at $10000 \mathrm{rpm}$ for 10 minutes to remove cell debris. A $\mathrm{pH}$ meter was used to determine the $\mathrm{pH}$ of the supernatant, and atomic absorption spectrophotometry was used to quantify the amount of available $\mathrm{Zn}$ in the supernatant (AAS-GBC, Australia). Using liquid Aleksandrow's medium supplemented with 0.1 percent potassium aluminium silicate, potassium solubilization was estimated at the $7^{\text {th }}$ and $9^{\text {th }}$ days of incubation, and the amount of ' $\mathrm{K}$ ' liberated in the broth was estimated. The solubilizing ability of culture media is often related to the degree of acidification of the medium; the $\mathrm{pH}$ of the culture supernatant was measured using a $\mathrm{pH}$ meter, and the available potash was estimated with a flame photometer.

\section{Ammonium production}

After 48 hours of incubation, isolates were tested for ammonia production by inoculating $100 \mu \mathrm{L}$ of bacterial culture in pre-sterilised peptone water and adding $0.5 \mathrm{~mL}$ of Nessler's reagent. Ammonia production was thought to be aided by a change in the medium's colour from brown to yellow (Kumar et al., 2015)

\section{Indole Acetic Acid (IAA) Production}

The active culture of each test isolate was maintained in $5 \mathrm{~mL}$ respective specified media broth tubes with $100 \mathrm{~mL}$ of L-tryptophan and incubated at $28 \pm 2{ }^{\circ} \mathrm{C}$ for 4 days to determine indole acetic acid production. Following incubation, these cultures were centrifuged at 3000 rpm for 30 minutes, and $2 \mathrm{~mL}$ supernatant was collected, along with two drops of O-phosphoric acid and $4 \mathrm{~mL}$ salkowski reagent $\left(0.5 \mathrm{M} \mathrm{FeCl}_{3}\right.$ in 35 percent perchloric acid) and incubated for 30 minutes to generate pink colour as a positive indicator of IAA generation, and optical density was measured at $530 \mathrm{~nm}$ using an UV-Visible spectrophotometer (Elico, India) and the concentrations were plotted against the standard graph (Bric et al., 1991).

\section{Gibberellic acid $\left(\mathbf{G A}_{3}\right)$ production}

Borrow and his coworkers (1955) developed a method for determining the gibberellic acidproducing capacity of bacterial strains (Loper, 1986). $100 \mathrm{~mL}$ sterile TSB was added to $1 \mathrm{~mL}$ culture broth in flasks and incubated at $37^{\circ} \mathrm{C}$ for seven days. After incubation, $15 \mathrm{ml}$ of cell-free supernatant was pipetted out of the broth culture after centrifugation at $8000 \mathrm{rpm}$ for 10 minutes, and two $\mathrm{ml}$ of zinc acetate solution $(21.9 \mathrm{~g}$ zinc acetate dissolved in $80 \mathrm{ml}$ distilled water and one $\mathrm{ml}$ glacial acetic acid, and the volume was raised up to $100 \mathrm{ml}$ with distilled water) was added and left for two minutes. Five millilitres of supernatant was collected, five millilitres of $30 \%$ hydrochloric acid was added, and the mixture was incubated for 75 minutes at $27^{\circ} \mathrm{C}$. At $430 \mathrm{~nm}$, absorbance was measured using a UV-VIS spectrophotometer. Each bacterial isolate's amount of $\mathrm{GA}_{3}$ liberated was determined and expressed in $\mathrm{g} \mathrm{mL}^{-1}$ broth.

\section{Siderophore Production}

The potential of bacterial isolates to produce siderophores was assessed qualitatively and quantitatively using the universal Chrome Azurol Sulphonate (CAS) test (Schwyn and Neilands, 1987). CAS agar plates were made by combining $100 \mathrm{~mL}$ CAS reagent with $900 \mathrm{~mL}$ sterilised Tryptone soy agar for the qualitative analysis (TSA). After eight bacterial isolates were spot 
injected on a single plate and incubated at $28^{\circ} \mathrm{C}$ for 5-7 days, the pigmented zone formed around the bacterial colonies.

For the quantitative experiment, 24-hour-old bacterial cultures were inoculated into sterile Tryptone soy broth (TSB) and incubated at $30^{\circ} \mathrm{C}$ for 24 hours at $120 \mathrm{rpm}$ with continual shaking. Following incubation, the fermented broth was centrifuged at $10000 \mathrm{rpm}$ for 15 minutes, and 100 $\mu 1$ of cell-free supernatant was used to estimate siderophores by placing $100 \mu 1$ of CAS reagent in separate wells of a microplate (CLS3474 Sigma). Following incubation, the optical density of each sample was measured using a microplate reader at $630 \mathrm{~nm}$ against a reference consisting of $100 \mu \mathrm{L}$ of uninoculated broth and $100 \mu \mathrm{l}$ of CAS reagent. Isolates' siderophores were measured in percent siderophore unit (psu), which was determined using the formula below (Payne, 1993).

Siderophore production $(\mathrm{psu})=(\mathrm{Ar}-\mathrm{As}) \times 100 \div \mathrm{Ar}$ Where $\mathrm{Ar}$ is the reference absorbance (CAS solution and uninoculated broth) and As is the sample absorbance (CAS solution and cell-free supernatant of sample).

\section{Hydrogen Cyanide (HCN) Production}

Castric \& Castric's technique for determining HCN production was used (1983). Under aseptic conditions, a strip of Whatmann filter paper No.1 $\left(10 \times 0.5 \mathrm{~cm}^{2}\right)$ was impregnated with an alkaline picric acid solution $(0.5$ percent picric acid $(\mathrm{w} / \mathrm{v})$ in 1 percent sodium carbonate) and inserted in the broth tubes containing individual bacterial cultures modified with glycine $(4.4 \mathrm{~g} / \mathrm{L})$. The tubes were incubated for $48-72$ hours at $28^{\circ} \mathrm{C}$. $\mathrm{HCN}$ production was determined by a change in filter paper colour from yellow to light brown or strong reddishbrown. The shift in colour is due to sodium picrate being reduced to a reddish compound proportional to the amount of HCN released. The colour was eluted by inserting the filter paper in a test tube with $10 \mathrm{ml}$ of distilled water and measuring the absorbance at $510 \mathrm{~nm}$.

Total cyanides contents $(\mathrm{ppm})=396 \times \mathrm{A}_{510}$

Where, $\mathrm{A}_{510}=$ absorbance at $510 \mathrm{~nm}$

\section{Pesticide compatibility assay}

The bacterial isolates were replicated in their respective broths and incubated for 48 hours at $28^{\circ} \mathrm{C}$ with continuous agitation at $150 \mathrm{rpm}$ on a rotary shaker. The bacterial cultures were centrifuged at $3750 \mathrm{rpm}$ for 20 minutes at $10^{\circ} \mathrm{C}$ to remove the supernatant and harvest the bacterial cells the bacterial cultures were centrifuged at 3750 $\mathrm{rpm}$ for 20 minutes at $10^{\circ} \mathrm{C}$ to remove the supernatant and harvest the bacterial cells.. To obtain a bacterial concentration of $10^{8} \mathrm{cfu} \mathrm{mL}^{-1}$, the supernatant was suspended in sterile phosphate buffer. Compatibility of test isolates was done with commonly used pesticides (Supplementary Table S1) following the Disc diffusion method. Dimethoate, imidacloprid, quinolphos, mancozeb, acephate and bavistin were used as test pesticides at eight different concentrations $0.01 \%, 0.05 \%, 0.1 \%$, $0.2 \%, 0.5 \%, 1.0 \%, 1.5 \%$ and $2 \%$ by maintaining four replications. $100 \mu \mathrm{l}$ bacterial suspension was spread on TSA media.Subsequently, sterile Whatmann paper plugs of $5 \mathrm{~mm}$ diameter were moistened with $50 \mu \mathrm{l}$ pesticide, at the mentioned concentrations, and placed on the surface of bacteria inoculated plates. All plates were incubated at $28^{\circ} \mathrm{C}$ for 72 hours before being examined for bacterial growth suppression (Mukherjee et al., 2017). Bacterial strain sensitivity to pesticides was measured based on the inhibition zone ( $\mathrm{mm}$ ) around the disc.

\section{Statistical Analysis}

According to Panse and Sukhatme (1954), the data from various experiments were statistically evaluated using Completely Randomized Design (CRD).

\section{Results and Discussion}

These eight bacterial isolates were chosen for their PGP characteristics, such as solubilization of phosphorus, zinc and potassium; production of siderophore, ammonia, IAA, $\mathrm{GA}_{3}, \mathrm{HCN}$ and compatibility with commonly used pesticides in crops (in vitro). The results are presented below.

Qualitative Assay for phosphorus, potassium and zinc solubilization by Plate Assay

Because phosphate solubilizing bacteria may convert insoluble phosphate to soluble orthophosphate ions that may be taken up and used by plants, the B120, B365, P69, AZB17, and ASP25 bacterial isolates demonstrated a zone of solubilization after 14 days of incubation by differing in their ability to solubilize TCP. The highest 'P' solubilization was noted for P69 with an index of 2.91 and $190 \%$ efficiency and Lowest was observed by B365 with a solubilization index (SI) of 2.36 and solubilization efficiency (SE) of 
$136.36 \%$. The solubilization results are shown in Figures 2a, 2b (Supplementary Table S2, Figure $\mathrm{S} 1)$. Isolates may solubilize ' $\mathrm{P}$ ' due to phosphatase synthesis or release of low molecular weight organic acids and production of inorganic acids such as sulphuric acid, nitric acid, and carbonic acid (Vyas and Gulati, 2009), generation of protons and ligands (Hinsinger et al., 2011), mobilise phytate (organic P) possibly by phytase synthesis (Jorquera et al., 2008). Pseudomonas isolate P33, Azospirillum (As-22) showed TCP solubilization (Desai, 2012).

Similarly, among all the eight isolates tested for ' $\mathrm{K}$ ' solubilization, only AZB17 could solubilize potassium aluminium silicate supplemented in Aleksandrow's medium, with a SI of 2.8 and $180 \%$ of SE as shown in Figure-2a, 2b (Supplementary Table S3, Figure S2). The release of potassium caused by the creation of a clearing zone surrounding the colonies could be related to exopolysaccharide synthesis.

All the selected bacterial isolates were able to solubilize $\mathrm{ZnO}$ and $\mathrm{ZnCO}_{3}$ except ASP34 which could solubilize only $\mathrm{ZnCO}_{3}$ when supplemented as an insoluble source and has shown the highest solubilization with an index of 5.33 and efficiency of $433.00 \%$. In $\mathrm{ZnO}$ amended media as insoluble mineral form, SI and SE were highest for B120 and least for B365 (8.75 and $775 \% ; 2.50$ and $150 \%$, respectively) (Supplementary Table S4, Figure S3, $\mathrm{S} 4)$. Hence, it is clear that $\mathrm{Zn}$ metal is known to be immobilised by bacteria by precipitation and adsorption. All the isolates differed significantly in their solubilization ability are shown in Figure 2a, 2b. In line with the results obtained, $\mathrm{Zn}$ solubilization efficiency of bacterial isolates collected from legume crop rhizosphere in $\mathrm{ZnO}$ modified media ranged from 117.2 percent to 466 percent, according to the Kumar et al., 2014 research group.

\section{Quantitative estimation of potassium solubilization efficiency}

The amount of potassium released from potassium aluminium silicate by all isolates rose with incubation time and peaked at 9 days after inoculation (DAI), according to the findings as shown in Figure-3. The ' $\mathrm{K}$ ' released from the broth by the isolate at 9 DAI measured using a flame photometer, ranged from $2.93 \mu \mathrm{g} \mathrm{mL}^{-1}$ to $6.25 \mu \mathrm{g}$
$\mathrm{mL}^{-1}$. With an increase in incubation time, a fall in $\mathrm{pH}$ was detected, resulting in media acidification (Supplementary Table S5). The increase in potassium solubilization and reduction in $\mathrm{pH}$ in culture broth over time could be due to the production of large amounts of organic acids that can form bidentate complexes with metal ions and chelate silicon ions, which are more effective in increasing mineral dissolution. Our findings are similar to those of Verma and colleagues' (2017) research, five bacterial strains, including four Pseudomonas sp. and one Azotobacter sp., were shown to be capable of releasing ' $\mathrm{K}$ ' from muscovite and biotite.

\section{Quantitative assay of $\mathrm{Zn}$ by $\mathrm{ZnO}$ and $\mathrm{ZnCO}_{3}$ as supplement sources}

The results showed significant heterogeneity in the isolates' ability to solubilize the same or different source of insoluble $\mathrm{Zn}$ compounds, which could be attributable to the generation of organic acids in the culture broth, such as gluconic acids (particularly 2keto-gluconic acids). Maximum solubilization of ' $\mathrm{Zn}$ ' with $0.1 \% \mathrm{ZnO}$ and $\mathrm{ZnCO}_{3}$ amended media was observed on 9 DAI by all the isolates. The available ' $\mathrm{Zn}$ ' concentration in $\mathrm{ZnO}$ and $\mathrm{ZnCO}_{3}$ amended broth was in the range of 14.8 to 21.3 ppm and 20.3 to $25.9 \mathrm{ppm}$, respectively on 9 DAI, when measured in AAS. Among all the isolates, B120 showed the highest solubilization with $\mathrm{ZnO}$ and also $\mathrm{ZnCO}_{3}$ with the lowest $\mathrm{pH}$ as shown in Figure 4a, 4b. On the other hand, AZB31 showed the lowest solubilization with $\mathrm{ZnO}$ and $\mathrm{B} 365$ with $\mathrm{ZnCO}_{3}$ as an insoluble mineral source, as shown in Figure $4 \mathrm{a}, 4 \mathrm{~b}$. The drop in $\mathrm{pH}$ of the culture medium was usually accompanied by an increase in incubation duration (Supplementary Table S6.1, S6.2). Microorganisms that solubilize zinc do so through a variety of methods, one of which is acidification through the release of organic acids (Alexander, 1997), chelated ligands and oxidoreductive systems on cell membranes (Chang et al., 2005). On inoculation of Bacillus sp., Azospirillum, and Pseudomonas aeruginosa to plants, they showed increased growth and zinc content (Fasim et al., 2002). From the results obtained we can conclude that the bacterial isolates of Bacillus, Pseudomonas, Azotobacter and Azospirillum were effective in solubilizing the inorganic insoluble forms of zinc, 


\begin{tabular}{|lllll|}
\hline & Phosphorous & Potassium & Zinc oxide & \multicolumn{2}{l|}{ Zinc carbonate } \\
B 120 & 2.64 & 0 & 8.75 & 4.09 \\
B 365 & 2.36 & 0 & 2.5 & 2.56 \\
P 48 & 0 & 0 & 3.17 & 4.5 \\
P 69 & 2.91 & 0 & 3.33 & 4.86 \\
AZB 17 & 2.9 & 2.8 & 3 & 4.75 \\
AZB 31 & 0 & 0 & 2.82 & 4.2 \\
ASP 25 & 2.5 & 0 & 3 & 4.8 \\
ASP 34 & 0 & 0 & 0 & 5.33 \\
\hline
\end{tabular}

Figure 2a: Solubilization index (SI) of bacterial isolates to solubilize different mineral sources (in vitro)

\begin{tabular}{|c|c|c|c|c|}
\hline & Phosphorous & Potassium & Zinc oxide & Zinc carbonate \\
\hline B 120 & 163.64 & 0 & 775 & 309.09 \\
\hline В 365 & 136.36 & 0 & 150 & 155.56 \\
\hline P 48 & 0 & 0 & 216.67 & 350 \\
\hline P 69 & 190.91 & 0 & 233.33 & 385.71 \\
\hline AZB 17 & 190 & 180 & 200 & 375 \\
\hline AZB 31 & 0 & 0 & 181.82 & 320 \\
\hline ASP 25 & 150 & 0 & 200 & 380 \\
\hline ASP 34 & 0 & 0 & 0 & 433.33 \\
\hline
\end{tabular}

Figure 2b: Solubilization efficiency (SE \%) of bacterial isolates to solubilize different mineral sources (in vitro)

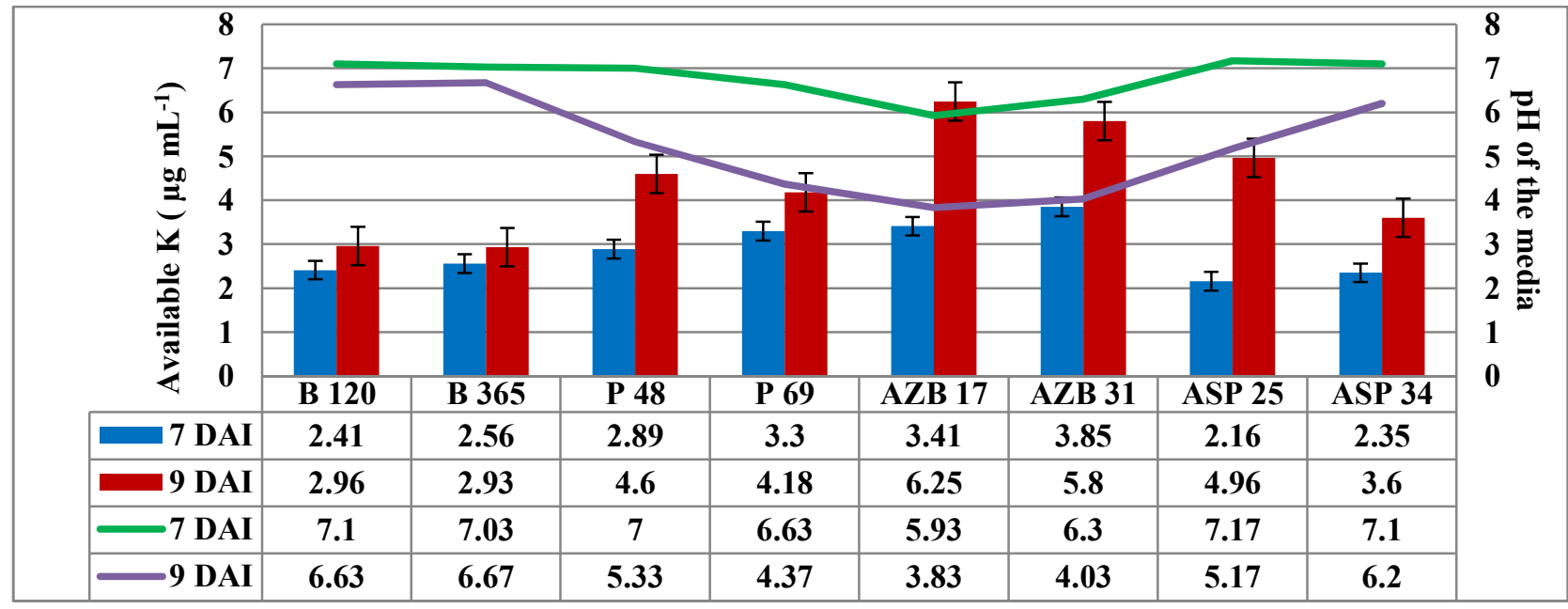

Figure 3: Evaluation of selected isolates for their ability to solubilize potassium present in the media over a while by decreasing the $\mathrm{pH}$ of the broth (in vitro) 


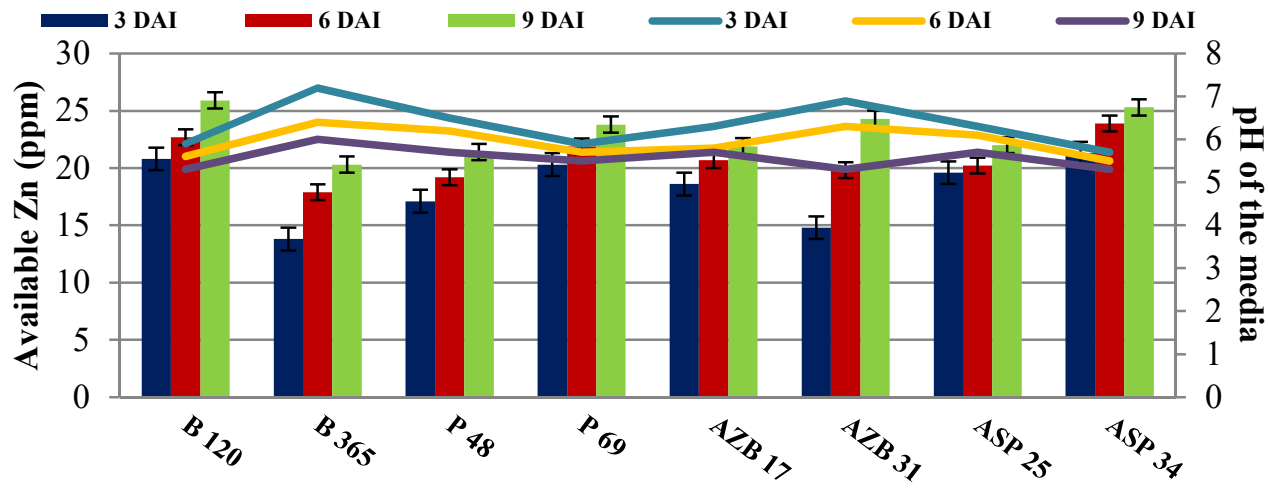

Bacterial isolates

Figure 4a: Evaluation of selected isolates for their ability to solubilize $\mathrm{Zn}$ present in $\mathrm{ZnO}$, over a period of time by decreasing the $\mathrm{pH}$ of the broth (in vitro)

Where, DAI is Days after inoculation, ppm is Parts per million

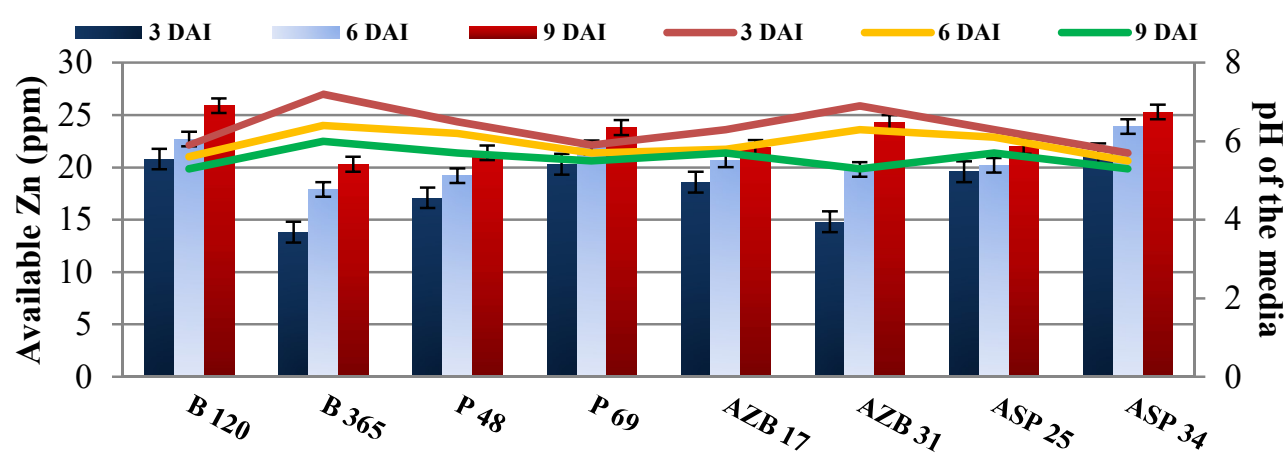

Bacterial isolates

Figure 4b: Evaluation of selected isolates for their ability to solubilize $\mathrm{Zn}$ present in $\mathrm{ZnCO}_{3}$ over a period of time by decreasing the $\mathrm{pH}$ of the broth (in vitro)

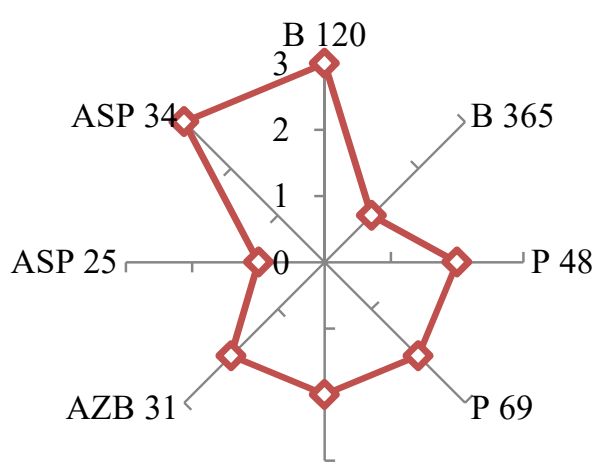

$\diamond-$ Intensity of ammonia liberated

AZB 17

Figure 5: Indication of Ammonia production by the bacterial isolates based on colour intensity (in vitro). The highest value showing isolates are strong ammonia producers (B120, ASP34), a medium value indicating moderate ammonia producers (P48, P69, AZB17, AZB31) and the lowest value showing isolates represents weak producer of ammonia (B365, ASP25) 
potassium, and phosphorous found in the soil and making them available for plant uptake, enhancing plant growth and improving crop production.

\section{Production of Ammonia (Qualitative assay)}

Ammonia production is an essential PGP feature of bacteria that indicates nitrogenase activity (Kundu and Gaur, 1984). Ammonia generation was detected in all of the PGPR isolates tested. When Nessler's reagent was added to the isolates cultured in peptone water, the broth colour changed brown to yellow, suggesting a positive test for ammonia generation. The isolates were divided into three categories based on colour intensity: strong, moderate, and weak. As shown in Figure-5, B120 and ASP34 were substantially positive; P48, P69, AZB17, AZB31 were moderately positive; and B365 and ASP25 were faintly positive (Supplementary Table S7, Figure S5). All of the ammonia-producing bacterial isolates give evidence for the ammonification process, which is a key part of the nitrogen cycle (Suja et al., 2010). Reeves et al., (1983) discovered that increasing the iron concentration boosted Azospirillum nitrogenase activity. Soil microorganisms that produce phytohormones can drive plant development and increase plant tolerance to a variety of biotic and abiotic challenges (Cho et al., 2015; Mustafa et al., 2020). IAA may be produced as a result of the conversion of tryptophan to indole-3-acetic aldehyde via a different mechanism than tryptamine formation. In Azotobacter, Bacillus, Azospirillum, and Pseudomonas, this pathway could provide a reason to operate.

Indole acetic acid (IAA) \& Gibberellic acid $\left(G_{3}\right)$ Production (Qualitative and Quantitative assay)

IAA is a signal molecule for plant development, stimulates root growth, and modifies root architecture, increases water absorption and water holding capacity. The data presented in Table-1 revealed the IAA produced by different isolates varied from 0.25 to $22.63 \mu \mathrm{g} \mathrm{mL}^{-1}$ after $72 \mathrm{~h}$ of incubation. The IAA production by ASP25 isolate was maximum and was statistically superior over all other isolates and the least was showed by P69 isolate. Similar findings were discovered by Islam and colleagues (2016), who tested 66 bacterial isolates from the cucumber rhizosphere and discovered that 10 isolates produced high quantities of IAA (26.78-51.28 $\left.\mathrm{g} \mathrm{mL}^{-1}\right)$. However, bacterial isolates produced variable amounts of IAA, which could be attributable to their involvement in biosynthetic pathways, gene placement, regulatory sequences, and the presence of enzymes that convert active free IAA into conjugated forms.

Another growth regulator, gibberellin, impacts seed germination, boosts plant development, and slows ageing (Gou et al., 2011), hence microorganisms were tested for their ability to produce $\mathrm{GA}_{3}$. All of the isolates were able to generate $\mathrm{GA}_{3}$ in a variation of quantities, 5.9 and $31.8 \mu \mathrm{g} \mathrm{mL}^{-1}$. All the isolates differed significantly as shown in Table 1 (Figure S6, S7). Similarly, the generation of GA and ABA by rhizosphere microorganisms has been widely reported in prior research (Janzen et al., 1992, Gutierrez et al., 2001). The studies of Kapoor et al., 2016 also indicated the generation of $\mathrm{GA}_{3}$ by Pyrus and Malus rhizospheric bacteria. In the genera Azotobacter spp., Bacillus spp., and Azospirillum spp., PGPB synthesis of GAs has been found (Deka et al., 2015; Dodd et al., 2010).

Siderophore \& HCN Production (Qualitative and Quantitative assay)

Another secondary metabolite produced during the stationary growth phase is cyanide (Knowles and Bunch, 1986). All eight bacterial isolates tested positive for HCN production capacity, which is thought to be linked to one of the microbes' biocontrol mechanisms. The ability of HCN synthesis, measured as Total Cyanide Content (TCC) in ppm was maximum by B120 (77.2 ppm) and the lowest by AZB17 (27.3 ppm) presented in Table 2 (Supplementary Figure S8, S9). HCN production varies between isolates, possibly because the oxidative decarboxylation route, which uses glycine as a precursor, produces $\mathrm{HCN}$ at higher rates (Trolldenier et al., 1986). Bacterial genera including Pseudomonas and Bacillus have been discovered to release HCN (Das et al., 2017; Zachow et al., 2017). The action of HCN has been linked to the suppression of Meloidogyne javanicacaused tomato root knot disease (Siddiqui et al., 2006).

Siderophore production is an indirect mode of biocontrol ability of microorganisms to chelate the iron and starve the pathogens for iron. All of the isolates tested positive for siderophore synthesis in this investigation. Table 2 shows that B120 exhibited maximum percent of siderophore units $(48.00 \%)$ followed by P69 which was $43.00 \%$ and 
Table 1: Screening of selected isolates for their ability to produce indole Acetic acid (IAA) and gibberellic acid $\left(\mathbf{G A}_{3}\right)$

\begin{tabular}{|l|l|l|}
\hline Isolates & $\mathbf{I A A} \boldsymbol{\mu} \mathbf{g} / \mathbf{m L}$ & $\mathbf{G A}_{\mathbf{3}} \boldsymbol{\mu} \mathbf{g} / \mathbf{m L}$ \\
\hline B 120 & $4.86 \pm 0.24$ & $5.96 \pm 0.30$ \\
\hline B 365 & $5.71 \pm 0.17$ & $22.31 \pm 0.08$ \\
\hline P 48 & $5.23 \pm 0.18$ & $27.63 \pm 0.96$ \\
\hline P 69 & $0.25 \pm 0.05$ & $31.89 \pm 0.32$ \\
\hline AZB 17 & $5.98 \pm 0.10$ & $22.39 \pm 0.39$ \\
\hline AZB 31 & $9.97 \pm 0.23$ & $8.32 \pm 0.19$ \\
\hline ASP 25 & $22.64 \pm 1.13$ & $26.27 \pm 1.31$ \\
\hline ASP 34 & $9.97 \pm 0.35$ & $22.32 \pm 0.77$ \\
\hline S.Em $( \pm)$ & 0.025 & 0.026 \\
\hline C.D. $(p=0.05)$ & 0.077 & 0.078 \\
\hline CV $\%$ & 0.545 & 0.213 \\
\hline
\end{tabular}

Table 2: Production of HCN and Siderophore by selected bacterial isolates

\begin{tabular}{|l|l|l|l|}
\hline Isolates & TCC (ppm) & psu (\%) \\
\hline B120 & $77.22 \pm 3.86$ & +++ & $48.87 \pm 2.44$ \\
\hline B365 & $40.78 \pm 0.43$ & ++ & $36.23 \pm 0.73$ \\
\hline P48 & $63.36 \pm 2.19$ & +++ & $22.25 \pm 0.77$ \\
\hline P69 & $72.86 \pm 0.99$ & +++ & $43.66 \pm 1.57$ \\
\hline AZB17 & $27.32 \pm 0.47$ & + & $12.27 \pm 0.21$ \\
\hline AZB31 & $72.86 \pm 1.68$ & +++ & $19.74 \pm 0.46$ \\
\hline ASP25 & $35.24 \pm 1.76$ & ++ & $6.51 \pm 0.33$ \\
\hline ASP34 & $32.87 \pm 1.14$ & ++ & $37.65 \pm 1.30$ \\
\hline S.Em $( \pm)$ & 0.023 & - & 0.007 \\
\hline C.D. $(p=0.05)$ & 0.071 & - & 0.022 \\
\hline CV \% & 0.079 & - & 0.044 \\
\hline
\end{tabular}

+++: High; ++: Medium; +: Low

\section{Inhibition of growth at concentrations of mancozeb (\%)}

\begin{tabular}{|c|c|c|c|c|c|c|c|c|}
\hline & 0.05 & 0.01 & 0.1 & 0.2 & 0.5 & 1 & 1.5 & 2 \\
\hline B120 & 0 & 0 & 0 & 0 & 5 & 5 & 6 & 6 \\
\hline B365 & 0 & 6 & 7 & 8 & 9 & 10 & 10 & 10 \\
\hline P48 & 0 & 0 & 0 & 0 & 3 & 7 & 8 & 9 \\
\hline P69 & 0 & 0 & 0 & 0 & 6 & 7 & 8 & 9 \\
\hline AZB17 & 0 & 0 & 0 & 0 & 7 & 8 & 8 & 8 \\
\hline AZB31 & 0 & 0 & 0 & 0 & 7 & 8 & 9 & 10 \\
\hline ASP25 & 0 & 0 & 0 & 0 & 0 & 0 & 0 & 0 \\
\hline ASP34 & 0 & 0 & 0 & 0 & 7 & 8 & 9 & 9 \\
\hline
\end{tabular}

Figure 6: Zone of Inhibition ( $\mathrm{mm}$ ) of selected bacterial isolates with mancozeb at different concentrations (Plate assay) 
ASP34 (37.00\%) (Supplementary Figure S10). Similar findings were made by Ahmad et al. (2008) showed that 12.77 percent of Azotobacter isolates were able to manufacture siderophores after screening 72 isolates belonging to Azotobacter, Pseudomonas, Mesorhizobium, and Bacillus. Bacillus halotolerans produced the most siderophores (73 percent), followed by Bacillus subtilis (69 percent), and Bacillus safensis (68 percent) in the quantitative estimation of siderophores (Sarwar et al., 2020).

\section{Compatibility of selected isolates with pesticides}

If the biological control approach has to be successful, the biocontrol agents should be compatible with the commonly used pesticides. All the eight potential isolates selected were compatible with carbendazim, acephate, imidacloprid, dimethoate and quinalphos at all concentrations and mancozeb at lower concentrations. Except for ASP25, remaining all bacterial isolates showed a zone of inhibition by the use of mancozeb. Zone of inhibition is a measure of the effectiveness of the pesticide (Figure 6). B365 was more sensitive to mancozeb at all concentrations except at $0.01 \%$. Hence only $0.01 \%$ concentration of mancozeb was a safe tolerance limit for B365. The isolates B120, B365, P48, P96, AZB17, AZB31 and ASP34 showed inhibition zone ranging from $3 \mathrm{~mm}$ to 10 $\mathrm{mm}$ on treating with mancozeb fungicide at $0.5 \%$, $1 \%, 1.5 \%$ and $2 \%$ concentrations.

\section{References}

Kumar, A., Shukla, U. K., Singh, A., Poonam, A. K., Prasad, S., Singh, S. K., \& Kumar, D. (2014). Evaluation of Pseudomonas isolates from wheat for some important plant growth promoting traits. African Journal of Microbiology Research, 8(27), 2604-2608.

Ahmad, F., Ahmad, I., \& Khan, M. S. (2008). Screening of free-living rhizospheric bacteria for their multiple plant growth promoting activities. Microbiological research, 163(2), 173-181.

Bhattacharyya, P. N., \& Jha, D. K. (2012). Plant growthpromoting rhizobacteria (PGPR): emergence in agriculture. World Journal of Microbiology and Biotechnology, 28(4), 1327-1350.

Beneduzi, A., Ambrosini, A., \& Passaglia, L. M. (2012). Plant growth-promoting rhizobacteria (PGPR): their potential as

\section{Conclusion}

There is a pressing need to develop efficient and cost-effective microorganisms that may be utilised singularly or in groups to ensure constant performance in the farmer's field. More research is needed to determine the quality of this PGPM in cropping systems. The microbiome has enormous potential for agricultural profit in terms of global food security, crop production sustainability, and establishing agricultural systems that are resilient to climate change. It's fascinating to go into the genomes of specific microorganisms to see if they're physiologically hardy enough to be useful in the field. By boosting soil fertility, plant tolerance, crop yield, and maintaining a balanced nutrient cycle, the use of modern technologies and techniques for enhancing PGPR with multidisciplinary analysis will play a significant role in sustainable agriculture, say the researchers. The study was undertaken to develop organic fertilizers and meet the requirements of ecofriendly crop farming packages. The research found that eight selected bacteria exhibit the features that can contribute to plant development and biocontrol activities.

\section{Acknowledgement}

This study was financially supported by Central research institute for dryland agriculture (ICARCRIDA), Hyderabad, India and Professor Jayashankar Telangana state agriculture university, Hyderabad, India.

antagonists and biocontrol agents. Genetics and molecular biology, 35, 1044-1051.

Borrow, A., Brian, P. W., Chester, V. E., Curtis, P. J., Hemming, H. G., Henehan, C., ... \& Radley, M. (1955). Gibberellic acid, a metabolic product of the fungus Gibberella fujikuroi: some observations on its production and isolation. Journal of the Science of Food and Agriculture, 6(6), 340-348.

Bric, J. M., Bostock, R. M., \& Silverstone, S. E. (1991). Rapid in situ assay for indoleacetic acid production by bacteria immobilized on a nitrocellulose membrane. Applied and environmental Microbiology, 57(2), 535-538.

Castric, K. F., \& Castric, P. A. (1983). Method for rapid detection of cyanogenic bacteria. Applied and Environmental Microbiology, 45(2), 701-702. 
Chang, H. B., Lin, C. W., \& Huang, H. J. (2005). Zinc-induced cell death in rice (Oryza sativa L.) roots. Plant growth regulation, 46(3), 261-266.

Cho, S. T., Chang, H. H., Egamberdieva, D., Kamilova, F., Lugtenberg, B., \& Kuo, C. H. (2015). Genome analysis of Pseudomonas fluorescens PCL1751: a rhizobacterium that controls root diseases and alleviates salt stress for its plant host. PLoS One, 10(10), e0140231.

Das, K., Prasanna, R., \& Saxena, A. K. (2017). Rhizobia: a potential biocontrol agent for soilborne fungal pathogens. Folia microbiologica, 62(5), 425-435.

Deka, H., Deka, S., \& Baruah, C. K. (2015). Plant growth promoting rhizobacteria for value addition: mechanism of action. In Plant-Growth-Promoting Rhizobacteria (PGPR) and Medicinal Plants (pp. 305-321). Springer, Cham.

Dobereiner, J., Marriel, I. E., \& Nery, M. (1976). Ecological distribution of Spirillum lipoferum Beijerinck. Canadian Journal of Microbiology, 22(10), 1464-1473.

Dodd, I. C., Zinovkina, N. Y., Safronova, V. I., \& Belimov, A. A. (2010). Rhizobacterial mediation of plant hormone status. Annals of Applied Biology, 157(3), 361-379.

Fasim, F., Ahmed, N., Parsons, R., \& Gadd, G. M. (2002). Solubilization of zinc salts by a bacterium isolated from the air environment of a tannery. FEMS microbiology letters, 213(1), 1-6.

Gou, J., Ma, C., Kadmiel, M., Gai, Y., Strauss, S., Jiang, X., \& Busov, V. (2011). Tissue-specific expression of Populus C19 GA 2-oxidases differentially regulate above-and below-ground biomass growth through control of bioactive GA concentrations. New Phytologist, 192(3), 626-639.

Hayat, R., Ali, S., Amara, U., Khalid, R., \& Ahmed, I. (2010). Soil beneficial bacteria and their role in plant growth promotion: a review. Annals of microbiology, 60(4), 579598.

Hinsinger, P., Betencourt, E., Bernard, L., Brauman, A., Plassard, C., Shen, J., ... \& Zhang, F. (2011). P for two, sharing a scarce resource: soil phosphorus acquisition in the rhizosphere of intercropped species. Plant physiology, 156(3), 1078-1086.

Janzen, R. A., Rood, S. B., Dormaar, J. F., \& McGill, W. B. (1992). Azospirillum brasilense produces gibberellin in pure culture on chemically-defined medium and in coculture on straw. Soil Biology and Biochemistry, 24(10), 1061-1064.

Jensen, H. L. (1940). Nitrogen fixation and cellulose decomposition by soil microorganisms. I. Aerobic cellulose-decomposers in association with azotobacter. In Proceedings of the Linnean Society of New South Wales (Vol. 65, pp. 543-556).
Jorquera, M. A., Hernández, M. T., Rengel, Z., Marschner, P., \& de la Luz Mora, M. (2008). Isolation of culturable phosphobacteria with both phytate-mineralization and phosphate-solubilization activity from the rhizosphere of plants grown in a volcanic soil. Biology and Fertility of Soils, 44(8), 1025-1034.

Kamilova, F., Okon, Y., de Weert, S., \& Hora, K. (2015). Commercialization of microbes: manufacturing, inoculation, best practice for objective field testing, and registration. In Principles of plant-microbe interactions (pp. 319-327). Springer, Cham.

Kapoor, R., Soni, R., \& Kaur, M. (2016). Gibberellins production by fluorescent Pseudomonas isolated from Rhizospheric soil of Malus and Pyrus. International journal of agriculture, environment and biotechnology, 9(2), 193-199.

King, E. O., Ward, M. K., \& Raney, D. E. (1954). Two simple media for the demonstration of pyocyanin and fluorescin. The Journal of laboratory and clinical medicine, 44(2), 301-307.

Knowles, C. J., \& Bunch, A. W. (1986). Microbial cyanide metabolism. Advances in microbial physiology, 27, 73-111.

Kumar, G. P., Desai, S., Amalraj, L., \& Reddy, G. (2015). Isolation of fluorescent Pseudomonas spp. from diverse agro-ecosystems of India and characterization of their PGPR traits. Bacteriology Journal, 5(1), 13-24.

Kundu, B. S., \& Gaur, A. C. (1984). Rice response to inoculation with $\mathrm{N}$ 2-fixing and P-solubilizing microorganisms. Plant and Soil, 79(2), 227-234.

Loper, J. E., \& Schroth, M. N. (1986). Influence of bacterial sources of indole-3-acetic acid on root elongation of sugar beet. Phytopathology, 76(4), 386-389.

Mhlongo, M. I., Piater, L. A., Madala, N. E., Labuschagne, N., \& Dubery, I. A. (2018). The chemistry of plant-microbe interactions in the rhizosphere and the potential for metabolomics to reveal signaling related to defense priming and induced systemic resistance. Frontiers in Plant Science, 9, 112.

Mukherjee, P., Roychowdhury, R., \& Roy, M. (2017). Phytoremediation potential of rhizobacterial isolates from Kans grass (Saccharum spontaneum) of fly ash ponds. Clean Technologies and Environmental Policy, 19(5), 1373-1385.

Mustafa, A., Naveed, M., Saeed, Q., Ashraf, M. N., Hussain, A., Abbas, T., ... \& Minggang, X. (2019). Application potentials of plant growth promoting rhizobacteria and fungi as an alternative to conventional weed control methods. Sustainable Crop Production. 
Naqqash, T., Hameed, S., Imran, A., Hanif, M. K., Majeed, A., \& van Elsas, J. D. (2016). Differential response of potato toward inoculation with taxonomically diverse plant growth promoting rhizobacteria. Frontiers in plant science, 7, 144.

Nirmal Kumar, J. I., Bora, A., \& Amb, M. K. (2010). Chronic toxicity of the triazole fungicide tebuconazole on a heterocystous, nitrogen-fixing rice paddy field cyanobacterium, Westiellopsis prolifica Janet. Journal of microbiology and biotechnology, 20(7), 1134-1139.

Payne, S. M. (1993). Iron acquisition in microbial pathogenesis. Trends in microbiology, 1(2), 66-69.

Reeves, M. W., Pine, L., Neilands, J. B., \& Balows, A. (1983). Absence of siderophore activity in Legionella species grown in iron-deficient media. Journal of Bacteriology, 154(1), 324-329.

Sarwar, S., Khaliq, A., Yousra, M., Sultan, T., Ahmad, N., \& Khan, M. Z. (2020). Screening of Siderophore-Producing PGPRs Isolated from Groundnut (Arachis hypogaea L.) Rhizosphere and Their Influence on Iron Release in Soil. Communications in Soil Science and Plant Analysis, 51(12), 1680-1692.

Schwyn, B., \& Neilands, J. B. (1987). Universal chemical assay for the detection and determination of siderophores. Analytical biochemistry, 160(1), 47-56.

Siddiqui, I. A., Shaukat, S. S., Sheikh, I. H., \& Khan, A. (2006). Role of cyanide production by Pseudomonas fluorescens $\mathrm{CHAO}$ in the suppression of root-knot nematode, Meloidogyne javanica in tomato. World Journal of Microbiology and Biotechnology, 22(6), 641-650.

Somers, E., Vanderleyden, J., \& Srinivasan, M. (2004). Rhizosphere bacterial signalling: a love parade beneath our feet. Critical reviews in microbiology, 30(4), 205-240.
Stefan, M., Munteanu, N., Stoleru, V., Mihasan, M. and Hritcu, L., 2013. Seed inoculation with plant growth promoting rhizobacteria enhances photosynthesis and yield of runner bean (Phaseolus coccineus L.). Scientia Horticulturae, 151: 22-29. https://doi.org/10.1016/j.scienta.2012.12.006

Suja, G., John, K. S., Sreekumar, J., \& Srinivas, T. (2010). Short-duration cassava genotypes for crop diversification in the humid tropics: growth dynamics, biomass, yield and quality. Journal of the Science of Food and Agriculture, 90(2), 188-198.

Trolldenier, G. (1987). Curl, EA and B. Truelove: The Rhizosphere.(Advanced Series in Agricultural Sciences, Vol. 15) Springer-Verlag, Berlin-Heidelberg-New YorkTokyo, 1986. 288 p, 57 figs., Hardcover DM 228.00, ISBN 3-540-15803-0.

Verma, P., Yadav, A. N., Khannam, K. S., Saxena, A. K., \& Suman, A. (2017). Potassium-solubilizing microbes: diversity, distribution, and role in plant growth promotion. In Microorganisms for green revolution (pp. 125-149). Springer, Singapore.

Vyas, P., \& Gulati, A. (2009). Organic acid production in vitro and plant growth promotion in maize under controlled environment by phosphate-solubilizing fluorescent Pseudomonas. BMC microbiology, 9(1), 1-15.

Zachow, C., Müller, H., Monk, J., \& Berg, G. (2017). Complete genome sequence of Pseudomonas brassicacearum strain L13-6-12, a biological control agent from the rhizosphere of potato. Standards in genomic sciences, 12(1), 1-7.

Zhang, X., Zhang, R., Gao, J., Wang, X., Fan, F., Ma, X., ... \& Deng, Y. (2017). Thirty-one years of rice-rice-green manure rotations shape the rhizosphere microbial community and enrich beneficial bacteria. Soil Biology and Biochemistry, 104, 208-217. 